\title{
What makes the hepatitis C virus evolve?
}

\section{Polymorphisms in the IFNL4 gene that affect both the presence and the form of the coded protein are associated with changes in the hepatitis $C$ virus.}

\author{
THOMAS R O'BRIEN, RUNE HARTMANN AND LUDMILA PROKUNINA-OLSSON
}

Related research article Chaturvedi N, Svarovskaia ES, Mo H, Osinusi AO. 2019. Adaptation of hepatitis $C$ virus to interferon lambda polymorphism across multiple viral genotypes. eLife 8:e42542. DOI: 10.7554/ eLife.42542

Related research article Ansari MA, Aranday-Cortes E, Ip CLC, da Silva Filipe A, Hin LS, Bamford CGG, Bonsall D, Trebes A, Piazza P, Sreenu V, Cowton VM, STOP-HCV Consortium, Hudson E, Bowden R, Patel AH, Foster GR, Irving WL, Agarwal K, Thomson EC, Simmonds P, Klenerman P, Holmes C, Barnes E, Spencer CCA, McLauchlan J, Pedergnana V. 2019. Interferon lambda 4 impacts the genetic diversity of hepatitis C virus. eLife 8:e42463. DOI: 10. 7554/eLife.42463

W hen cells are infected with a virus they release proteins known as interferons to fight off the infection. In

(c) Copyright O'Brien et al. This is an open-access article, free of all copyright, and may be freely reproduced, distributed, transmitted, modified, built upon, or otherwise used by anyone for any lawful purpose. The work is made available under the Creative Commons CCO public domain dedication.
2003, a group of proteins called interferon lambda, or IFN- $\lambda$ for short, were found to activate anti-viral signaling pathways used by other interferons (Kotenko et al., 2003; Sheppard et al., 2003). It was initially thought that members of the IFN- $\lambda$ family were simply redundant to well-known interferons. However, a growing body of evidence indicates IFN- $\lambda$ proteins provide unique 'first-line' protection against a wide range of common viruses that can infect the respiratory and gastrointestinal tracts, as well as the brain (Ye et al., 2019).

IFN- $\lambda 4$ is the most recently discovered member of the IFN- $\lambda$ family. Production of IFN- $\lambda 4$ in humans depends on which variant of the IFNL4 gene a person carries. Individuals with the IFNL4- $\Delta \mathrm{G}$ variant can synthesize the full protein, while those with the IFNL4-TT variant produce a truncated protein that is not functional (Prokunina-Olsson et al., 2013). Another polymorphism called IFNL4 P70S produces variants of the full protein with different biological activity: if the amino acid in position 70 is a proline, the protein is fully active, but if it is a serine the protein has reduced biological activity (TerczyńskaDyla et al., 2014). These IFNL4 genetic variants affect clearance of the hepatitis $C$ virus, and have been associated with the risk of other conditions. These conditions include a rare form of ovarian cancer, more aggressive prostate cancer and liver inflammation and scarring caused by the hepatitis $B$ and $C$ viruses or non-alcoholic fatty liver disease (Eslam et al., 2015; Kelemen et al., 2015; Minas et al., 2018).

Worldwide, an estimated 71 million people are infected with hepatitis $C$ virus. There are various genotypes and subtypes of $\mathrm{HCV}$ and, like other RNA viruses, HCV frequently mutates and can undergo selection for different viral variants. This genetic variability is clinically significant, as some changes in the HCV genome may impair the effectiveness of certain treatments. Paradoxically, although interferons are usually antiviral 
proteins, patients with the most biologically active form of IFN- $\lambda 4$ are least likely to clear HCV. On the other hand, patients with the IFNL4-TT allele that do not produce active IFN- $\lambda$ 4 have the highest rates of spontaneous clearance and response to treatment (ProkuninaOlsson et al., 2013; Terczyńska-Dyla et al., 2014).

Now, in eLife, two collaborations report on the effect of IFNL4 genotype on the HCV viral genome. Previously, in 2017, Azim Ansari, Vincent Pedergnana and colleagues at the University of Oxford and other institutions reported the results of a genome-to-genome analysis which revealed that the HCV genome evolves in response to the genome of the infected individual (Ansari et alo, 2017). The analysis showed that HCV viral levels (number of virus particles) and the amino acid sequence of viral proteins depended on whether the patient had the IFNL4-TT or the IFNL4- $\Delta G$ gene variant. In the new elife papers, researchers based in Oxford, Lausanne and elsewhere examine the association between host IFNL4 genotype and viral genome variations more broadly.

In one paper, Ansari, Pedergnana and coworkers - including Elihu Aranday-Cortes and John McLauchlan of the MRC-University of Glasgow Centre for Virus Research - report that the presence of IFN- $\lambda 4$, and also its biological activity, both affect how HCV evolves (Ansari et al., 2019). Ansari et al. analyzed the IFNL4 genotypes of 485 patients with chronic HCV and the genomes of the virus with which they were infected. To avoid confounding factors, the analysis was restricted to patients of white ancestry infected with HCV genotype 3a. In this new work they show that in addition to the effect of the IFNL4- $\Delta \mathrm{G} / \mathrm{TT}$ variant, the IFNL4 P70S polymorphism, which modulates IFN- $\lambda 4$ activity, affects the amino acid sequence of $\mathrm{HCV}$.

In the other elife paper, Nimisha Chaturvedi, Jacques Fellay (both of the EPFL and the Swiss Institute of Bioinformatics) and colleagues at Gilead Sciences and Goethe University Hospital report the results of a study that included 8729 patients who were infected with a range of $\mathrm{HCV}$ genotypes (Chaturvedi et alı, 2019). This investigation revealed that the polymorphism rs12979860, which serves as a marker for IFNL4$\Delta \mathrm{G} / \mathrm{TT}$, is associated with amino acid changes in viral proteins across viral genotypes. Different viral polymorphisms were affected in the different viral genotypes. Taken together these new results show IFN- $\lambda 4$ drives hepatitis $C$ evolution across multiple viral genotypes and that not simply the presence, but also the form of IFN- $\lambda 4$ contributes to this effect.

How IFN- $\lambda 4$ makes $\mathrm{HCV}$ evolve remains unknown. Future studies should attempt to elucidate this mechanism, although currently such work is hampered by the transient and cell-specific expression of IFNL4 in human tissues, and the lack of animal models - neither mice nor rats carry the gene. As the IFN- $\lambda$ family is known to play a role in a wide range of viral infections, it would be interesting to see whether variants of the IFNL4 gene affect response to those infections or can drive the evolution of viruses other than HCV. The hypothesis that IFNL4 genotype affects infections other than HCV is further supported by evidence showing that there has been strong evolutionary selection for IFNL4-TT, the variant of the gene that produces an inactive truncated protein (Key et al., 2014).

\section{Disclaimer}

The content of this publication does not necessarily reflect the views or policies of the Department of Health and Human Services, nor does mention of trade names, commercial products, or organizations imply endorsement by the US Government.

\section{Acknowledgements}

This work was supported by the Intramural Research Program of the National Institutes of Health, National Cancer Institute, Division of Cancer Epidemiology and Genetics.

Thomas R O'Brien is in the Infections and Immunoepidemiology Branch, Division of Cancer Epidemiology and Genetics, National Cancer Institute, National Institutes of Health, Bethesda, United States obrient@exchange.nih.gov (iD) https://orcid.org/0000-0003-0003-6065

Rune Hartmann is in the Department of Molecular Biology at the University of Aarhus, Aarhus, Denmark (iD) https://orcid.org/0000-0003-1159-066X

Ludmila Prokunina-Olsson is in the Laboratory of Translational Genomics, Division of Cancer Epidemiology and Genetics, National Cancer Institute, National Institutes of Health, Bethesda, United States (D) https://orcid.org/0000-0002-9622-2091

Competing interests: Thomas $\mathrm{R} \mathrm{O}^{\prime} \mathrm{Brien}: \mathrm{TRO} \mathrm{B}$ : Coinventor (with LP-O) on a patent for the IFN- $\lambda 4$ protein held by the National Cancer Institute. Ludmila Prokunina-Olsson: LP-O: Co-inventor (with TRO'B) on a patent for the IFN- $\lambda 4$ protein held by the National Cancer 
Institute. The other author declares that no competing interests exist.

Published 03 September 2019

\section{References}

Ansari MA, Pedergnana V, Ip CLC, Magri A, Von Delft A, Bonsall D, Chaturvedi N, Bartha I, Smith D, Nicholson G, McVean G, Trebes A, Piazza P, Fellay J, Cooke G, Foster GR, STOP-HCV Consortium, Hudson E, McLauchlan J, Simmonds P, Bowden R, et al. 2017. Genome-to-genome analysis highlights the effect of the human innate and adaptive immune systems on the hepatitis C virus. Nature Genetics 49:666-673. DOI: https://doi.org/10.1038/ng.3835, PMID: 283 94351

Ansari MA, Aranday-Cortes E, Ip CLC, da Silva Filipe A, Hin LS, Bamford CGG, Bonsall D, Trebes A, Piazza P, Sreenu V, Cowton VM, STOP-HCV Consortium, Hudson $E$, Bowden R, Patel AH, Foster GR, Irving WL, Agarwal K, Thomson EC, Simmonds P, Klenerman P, et al. 2019. Interferon lambda 4 impacts the genetic diversity of hepatitis C virus. elife 8:e42463. DOI: https://doi.org/10.7554/eLife.42463

Chaturvedi N, Svarovskaia ES, Mo H, Osinusi AO. 2019. Adaptation of hepatitis $C$ virus to interferon lambda polymorphism across multiple viral genotypes. eLife 8:e42542. DOI: https://doi.org/10.7554/eLife. 42542

Eslam M, Hashem AM, Leung R, Romero-Gomez M, Berg T, Dore GJ, Chan HL, Irving WL, Sheridan D, Abate ML, Adams LA, Mangia A, Weltman M, Bugianesi E, Spengler U, Shaker O, Fischer J, Mollison $L$, Cheng W, Powell E, et al. 2015. Interferon- $\lambda$ rs12979860 genotype and liver fibrosis in viral and non-viral chronic liver disease. Nature Communications 6:6422. DOI: https://doi.org/10.1038/ncomms7422, PMID: 25740255

Kelemen LE, Lawrenson K, Tyrer J, Li Q, Lee JM, Seo JH, Phelan CM, Beesley J, Chen X, Spindler TJ, Aben $\mathrm{KK}$, Anton-Culver $\mathrm{H}$, Antonenkova N, Australian Cancer Study, Australian Ovarian Cancer Study Group, Ovarian Cancer Association Consortium. 2015. Genome-wide significant risk associations for mucinous ovarian carcinoma. Nature Genetics 47:888-897. DOl: https://doi.org/10.1038/ng.3336, PMID: 260757 90

Key FM, Peter B, Dennis MY, Huerta-Sánchez E, Tang W, Prokunina-Olsson L, Nielsen R, Andrés AM. 2014. Selection on a variant associated with improved viral clearance drives local, adaptive pseudogenization of interferon lambda 4 (IFNL4). PLOS Genetics 10: e1004681. DOI: https://doi.org/10.1371/journal.pgen. 1004681, PMID: 25329461

Kotenko SV, Gallagher G, Baurin VV, Lewis-Antes A, Shen M, Shah NK, Langer JA, Sheikh F, Dickensheets $H$, Donnelly RP. 2003. IFN- $\lambda$ s mediate antiviral protection through a distinct class II cytokine receptor complex. Nature Immunology 4:69-77. DOI: https:// doi.org/10.1038/ni875, PMID: 12483210

Minas TZ, Tang W, Smith CJ, Onabajo OO, Obajemu A, Dorsey TH, Jordan SV, Obadi OM, Ryan BM, Prokunina-Olsson L, Loffredo CA, Ambs S. 2018. IFNL4- $\Delta \mathrm{G}$ is associated with prostate cancer among men at increased risk of sexually transmitted infections. Communications Biology 1:191. DOI: https://doi.org/10.1038/s42003-018-0193-5, PMID: 30456312

Prokunina-Olsson L, Muchmore B, Tang W, Pfeiffer RM, Park $H$, Dickensheets $H$, Hergott $D$, Porter-Gill $P$, Mumy A, Kohaar I, Chen S, Brand N, Tarway M, Liu L, Sheikh F, Astemborski J, Bonkovsky HL, Edlin BR, Howell CD, Morgan TR, et al. 2013. A variant upstream of IFNL3 (IL28B) creating a new interferon gene IFNL4 is associated with impaired clearance of hepatitis $C$ virus. Nature Genetics 45:164-171. DOI: https://doi.org/10.1038/ng.2521, PMID: 232915 88

Sheppard P, Kindsvogel W, Xu W, Henderson K, Schlutsmeyer $S$, Whitmore TE, Kuestner R, Garrigues U, Birks C, Roraback J, Ostrander C, Dong D, Shin J, Presnell S, Fox B, Haldeman B, Cooper E, Taft D, Gilbert T, Grant FJ, et al. 2003. IL-28, IL-29 and their class II cytokine receptor IL-28R. Nature Immunology 4:63-68. DOI: https://doi.org/10.1038/ni873, PMID: 12469119 Terczyńska-Dyla E, Bibert S, Duong FH, Krol I, Jørgensen S, Collinet E, Kutalik Z, Aubert V, Cerny A, Kaiser L, Malinverni R, Mangia A, Moradpour D, Müllhaupt B, Negro F, Santoro R, Semela D, Semmo N, Swiss Hepatitis C Cohort Study Group, Heim MH, Bochud PY, et al. 2014. Reduced IFN $\lambda 4$ activity is associated with improved HCV clearance and reduced expression of interferon-stimulated genes. Nature Communications 5:5699. DOI: https://doi.org/10. 1038/ncomms6699, PMID: 25534433

Ye L, Schnepf D, Becker J, Ebert K, Tanriver Y, Bernasconi V, Gad HH, Hartmann R, Lycke N, Staeheli P. 2019. Interferon- $\lambda$ enhances adaptive mucosal immunity by boosting release of thymic stromal lymphopoietin. Nature Immunology 20:593-601. DOI: https://doi.org/10.1038/s41590-019-0345-x, PMID: 30886417 